\title{
FINANČNÍ KONDICE OBCÍ JIHOMORAVSKÉHO KRAJE
}

\section{FINANCIAL CONDITION OF MUNICIPALITIES IN THE SOUTH MORAVIAN REGION}

\author{
ING. IRENA OPLUŠTILOVÁ, PH.D. \\ Ing. Petr halÁMeK, Ph.D. \\ Katedra regionální ekonomie a správy $\mid$ Dep. of Regional Economics and Administration \\ Ekonomicko-správní fakulta Faculty of Economics and Administration \\ Masarykova univerzita Masaryk University \\ $\bowtie$ Lipová 4la, 60200 Brno, Czech Republic \\ E-mail:oplustii@econ.muni.cz,halamek@econ.muni.cz
}

\begin{abstract}
Anotace
Př́spěvek se zabývá hodnocením finančni kondice obcí, tj. schopností financovat rozvojové investice. Metodika je založena na hodnoceni soustavy ukazateli̊ založených na finančních výsledcích obce vletech 2009-11. Výsledkem výzkumu je zejména identifikace obci s problematickou finančni kapacitou. Tyto obce se mély primárně soustředit na hledáni úspor v provozni části rozpočtu, připadně hledat cesty na navýšeni svých běžných přijmů.
\end{abstract}

\section{Klíčová slova}

rozpočet obce, deficit, zadluženost, finanční kondice

\section{Annotation}

The paper deals with the municipal financial condition, ie the ability of municipalities to fund development investment. The methodology is based on the original evaluation system using indicators based on the financial results in years 2009-11. The result of the research is identification of municipalities with problematic financial capacity. These municipalities should be primarily focused on finding savings in the operating budget or looking for ways to increase their operational income.

\section{Keywords}

municipal Budget, Deficit, Debt, Financial condition

\section{JEL classification: $H 72$}

\section{Úvod}

Pojem finanční kondice obce (financial condition) vychází z konceptu finančního zdraví a zaměřuje se zejména na finanční aspekty fungování subjektu. Konkrétní vymezení (a tedy i zahrnutí či nezahrnutí jiných než finančních ukazatelů) pak vychází z účelu hodnocení finanční kondice. Zhodnocení finanční situace obce je důležitým předpokladem pro kvalifikované rozhodování o dalších krocích obce. Přitom informace o finančním zdraví obce jsou podstatné nejen pro samotné obce, jejich představitele a občany, ale i pro různé další subjekty, at' už z okruhu veřejné či soukromé sféry (srov. Opluštilová, 2012).

\section{Cíle výzkumu a použitá metodika}

Cílem tohoto příspěvku je na základě zvolených ukazatelů zhodnotit finanční kondici obcí Jihomoravského kraje ve smyslu jejich možnosti financovat své investiční záměry (at' už formou 
dosahování úspor či formou dluhového financování a splácení těchto dluhů). S ohledem na zvolený účel byly zvoleny základní ukazatele, které postihují oblast rozpočtového hospodaření a zadluženost obce. Výpočty ukazatelů jsou provedeny s využitím dat za roky 2009 až 2011.

Výpočty zvolené soustavy ukazatelů jsou provedeny Pro všech 672 obcí nacházejících se na území Jihomoravského kraje. Výsledky jsou hodnoceny a interpretovány v souhrnu za všechny zpracované obce a dále v rozdělení dle vybraných velikostních skupin (0-199, 200-4999, 500-999, 1 000-1 999, 2 000-4 999, 5 000-9 999, 10 000-99 999, 100000 a více). Oproti velikostním kategoriím standardně využívaných Českým statistickým úřadem došlo pro potřeby výzkumu vzhledem k nízkému počtu subjektů ke sloučení velikostních kategorií nad 10000 obyvatel do jedné, do které však není zahrnuto statutární město Brno. Vzhledem k jeho naprosto odlišné velikosti od ostatních měst $\mathrm{z}$ této kategorie výsledky za toto město vstupují pouze do souhrnných výpočtů za obce celkem.

Studie čerpá data $z$ veřejně dostupných zdrojů. Informace o počtu obyvatel obcí jsou převzaty z Českého statistického úřadu, finanční data jsou čerpána z výkazů pro hodnocení plnění rozpočtu ÚSC a z rozvah obcí, které jsou publikovány v databázích ARIS a ÚFIS Ministerstva financí ČR. Výjimkou jsou některá finanční data za statutární město Brno, kdy byla použita data publikovaná v Závěrečném účtu statutárního města Brna za př́slušný rok. Důvodem je zvolený způsob klasifikace a účtování převodů mezi městem a jeho městskými částmi ${ }^{1}$.

Jako základní ukazatele byl zvolen ukazatel salda provozního rozpočtu (UR1) a dva ukazatele zadluženosti, které vyjadřují náročnost ročních výdajů na zadluženost (UZ1) a celkový stav zadlužení (UZ2).

UR1 (ukazatel salda provozního rozpočtu) - v oblasti rozpočtového hospodaření byl s ohledem na významnost, omezení interpretace a vhodnosti pro srovnání mezi obcemi vybrán jeden, avšak zásadní ukazatel provozního (běžného) rozpočtu. Ukazatel podílu přebytku provozního rozpočtu na běžných př́ijmech ${ }^{2}$ hodnotí základní předpoklad úspěšného hospodaření obcí, tedy dosahování přebytku v provozní části rozpočtu.

UZ1 - ukazatel podílu dluhové služby a dluhové kapacity vyjadřuje, jak je obec schopna hradit své závazky ze salda provozního rozpočtu. Výpočet salda provozního rozpočtu je mírně modifikovaný, do běžných výdajů nejsou zahrnuty placené úroky, protože ty tvoří součást dluhové služby a úkolem ukazatele je zjistit, zda a jak dokáže obec zajistit prostředky právě také na jejich úhradu. Dluhová služba je vypočitána jako součet placených úroků a uhrazených splátek úvěrů, půjček a ročních podílů emitovaných dluhopisů; $v$ př́padě splátek krátkodobých půjčených prostředků byl do výpočtu zahrnut pouze prrípadný kladný rozdíl položek $8 \times 14$ minus $8 \times 13$, tedy rozdíl splátek a prrijatých půjčených prostředků, aby byl vyloučen negativní vliv případných kontokorentů či obdobných finančních produktů na výsledné hodnocení ukazatele. Tento ukazatel byl zvolen z toho důvodu, že oproti známějšímu ukazateli dluhové služby bere v úvahu existující (či neexistující) prostředky obce, které lze vynaložit na dluhovou službu, kdežto UDS pouze předpokládá, že obec může určitý podíl vybraných druhů př́ijmů na dluhovou službu vynaložit.

UZ2 - ukazatel podílu celkového dluhu na saldu provozního rozpočtu vyjadřuje, za kolik let je obec schopna při dané úrovni salda BR své dluhy splatit právě z tohoto salda. Ukazatel postihuje vlastní aktivitu a př́istup obce k plánování svých závazků a k jejich možnému splácení. I když obec nemůže ovlivnit podstatnou část svých běžných prŕjmů i běžných výdajů, musí brát jejich výši v úvahu při rozhodování o dalším zatížení obecního rozpočtu v př́ípadě zadlužení obce, musí brát ohled na fakt, zda a v jakém časovém horizontu je obec schopná splatit své dluhy.

\footnotetext{
${ }^{1}$ Převody mezi městem a městskými částmi v rozpočtu zobrazuje jako převody mezi různými obcemi v rámci jednoho okresu, pro vyloučení těchto převodů je třeba konsolidovat data až na úrovni okresu.

${ }^{2}$ Do běžných př́ijmů jsou zahrnuty daňové př́ijmy, nedaňové př́íjmy a neinvestiční přijaté transfery.
} 
V následujících tabulkách je uveden přehled používaných finančních dat a způsoby výpočtu jednotlivých ukazatelů. Vzhledem k účetní reformě veřejných financí došlo od r. 2010 ke změně účtování obcí a tedy mimo jiné i ke změně směrné účtové osnovy, jsou uvedeny způsoby výpočty ukazatelů v rozdělení pro rok 2009 a roky 2010 a následující.

Tab. 1: Kategorie používaných finančních dat

\begin{tabular}{|c|c|c|c|c|}
\hline & kategorie & zdroj & položka, účet 2009 & položka, účet 2010, 2011 \\
\hline A & daňové př́ijmy & rozpočet & součet položek 1xxx & součet položek 1xxx \\
\hline $\mathrm{B}$ & nedaňové př́íjmy & rozpočet & součet položek 2xxx & součet položek 2xxx \\
\hline $\mathrm{C}$ & přijaté neinvestiční transfery & rozpočet & $\begin{array}{l}\text { součet položek } 41 \mathrm{xx} \text { po } \\
\text { konsolidaci }\end{array}$ & $\begin{array}{l}\text { součet položek } 41 \mathrm{xx} \text { po } \\
\text { konsolidaci }\end{array}$ \\
\hline $\mathrm{D}$ & běžné výdaje & rozpočet & pol. 5xxx po konsolidaci & pol. 5xxx po konsolidaci \\
\hline $\mathrm{E}$ & placené úroky & rozpočet & součet položek 5141 & součet položek 5141 \\
\hline $\mathrm{F}$ & splátky emitovaných dluhopisů & rozpočet & součet položek 8xx2 & součet položek 8xx2 \\
\hline G & \begin{tabular}{|l}
$\begin{array}{l}\text { krátkodobé přijaté půjčené } \\
\text { prostředky }\end{array}$ \\
\end{tabular} & rozpočet & součet položek $8 \times 13$ & součet položek $8 \times 13$ \\
\hline $\mathrm{H}$ & $\begin{array}{l}\text { splátky krátkodobých přijatých } \\
\text { půjčených prostředků }\end{array}$ & rozpočet & součet položek 8x14 & součet položek $8 \times 14$ \\
\hline I & $\begin{array}{l}\text { splátky dlouhodobých přijatých } \\
\text { půjčených prostředků }\end{array}$ & rozpočet & součet položek 8x24 & součet položek 8x24 \\
\hline $\mathrm{J}$ & celkový dluh & rozvaha & $\begin{array}{l}\text { syntetické účty } \\
281+282+283+289+322+ \\
326+951+953+959\end{array}$ & $\begin{array}{l}\text { syntetické účty } \\
281+282+283+289+322+ \\
326+451+452+453+459\end{array}$ \\
\hline
\end{tabular}

Vysvětlivky - data z rozvahy:

281 - krátkodobé úvěry

282 - eskontované krátkodobé dluhopisy (směnky)

283 - krátkodobé závazky z vydaných dluhopisů

289 - jiné krátkodobé půjčky

322 - směnky k úhradě

326 - přijaté návratné finanční výpomoci krátkodobé (do r. 2009 bez časového hlediska)

451 - dlouhodobé úvěry (951 do r. 2009)

452 - přijaté návratné finanční výpomoci dlouhodobé

453 - dlouhodobé závazky z vydaných dluhopisů (953 do r. 2009)

459 - ostatní dlouhodobé závazky (959 do r. 2009)

Tab. 3: Výpočet ukazatelů finanční kapacity obcí

\begin{tabular}{|c|l|c|}
\hline ukazatel & \multicolumn{1}{|c|}{ výpočet } & úpravy výsledku \\
\hline $\mathrm{UR} 1$ & $(\mathrm{~A}+\mathrm{B}+\mathrm{C}-\mathrm{D}) /(\mathrm{A}+\mathrm{B}+\mathrm{C})$ & - \\
\hline $\mathrm{UZ} 1$ & $(\mathrm{E}+$ roční podíl $\mathrm{F}+(\mathrm{H}-\mathrm{G}) *+\mathrm{I}) /(\mathrm{A}+\mathrm{B}+\mathrm{C}-(\mathrm{D}-\mathrm{E}))$ & $\mathrm{když} \mathrm{UZ1}<0 ; \mathrm{UZ} 1=-1$ \\
\hline $\mathrm{UZ2} 2$ & $\mathrm{H} /(\mathrm{A}+\mathrm{B}+\mathrm{C}-\mathrm{D})$ & $\mathrm{když} \mathrm{UZ2}<0 ; \mathrm{UZ2}=-1$ \\
\hline
\end{tabular}

\section{Výsledky}

Ukazatel UR1 vyjadřuje schopnost obce vytvářet přebytek v provozní části rozpočtu. Srovnání výsledků tohoto ukazatele může být mírně nevýhodné pro obce, které plní větší rozsah úkolů v přenesené působnosti a na tyto činnosti získávají neinvestiční transfery. V čitateli ukazatele tak budou zahrnuty výdaje i př́imy související s touto činností, ovšem ve jmenovateli budou zahrnuty pouze př́ijmy - veškeré neinvestiční transfery. Při hodnocení výsledků je třeba brát v úvahu omezenou možnost obce aktivně získávat běžné prŕijmy a oproti tomu nutnost hradit zejména mandatorní výdaje. Ukazatel je vhodný k hodnocení finanční situace konkrétní obce a při znalosti trendů běžné př́imové i 
výdajové stránky rozpočtu se jedná o velmi důležitý ukazatel pro plánování budoucích aktivit obce (provozních i investičních). Následující graf prezentuje průměrné výsledky tohoto ukazatele v obcích Jihomoravského kraje v rozdělení dle velikostních kategorií. Jak již bylo zmíněno, do rozdělení dle velikostních kategorií nebylo zařazeno statutární město Brno, avšak jeho výsledky vstupují do výpočtů dat za obce celkem.

Obr. 1: Průmèrná výše úspory provozního rozpočtu obcí JMK

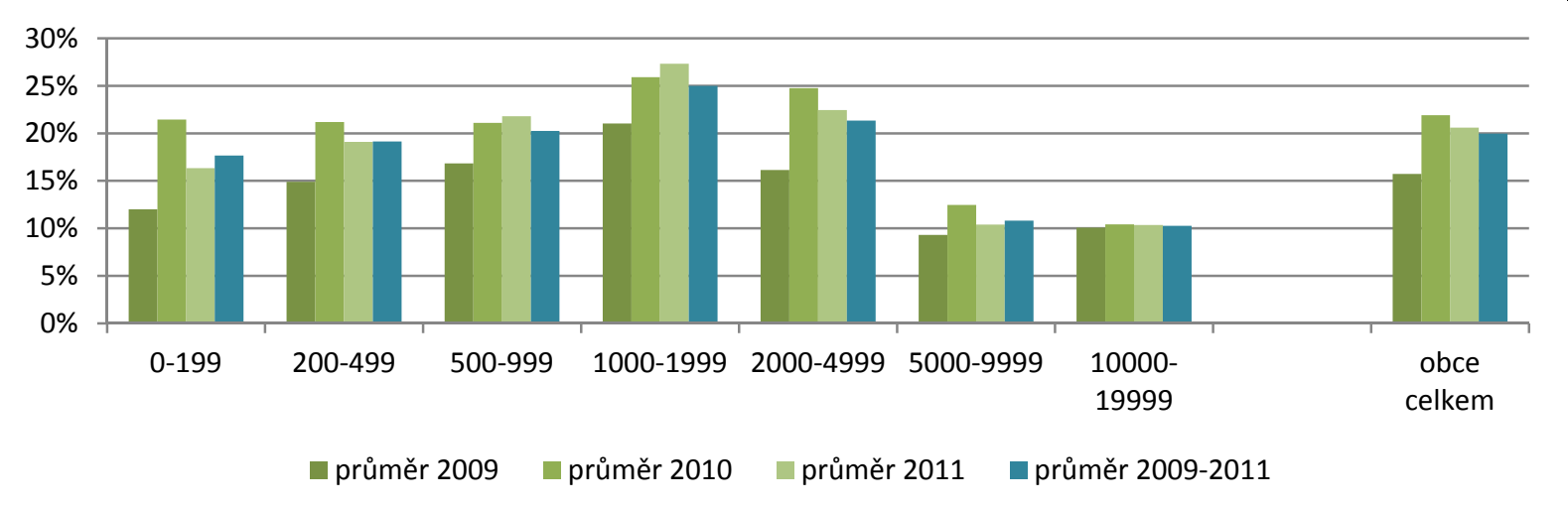

Zdroj: ČSÚ:počet obyvatel v obcích k 1.1.2009, 2010, 2011; databáze ARIS, ÚFIS MFČR; Závěrečný účet statutárniho města Brna za rok 2009, 2010, 2011. Vlastni zpracování.

Další graf prezentuje procentní zastoupení obcí se zápornou výší salda provozního rozpočtu v jednotlivých velikostních kategoriích. Schopnost generovat úspory v provozním rozpočtu představuje základní předpoklad pro dobrou finanční situaci obce a pro její možnosti rozvoje. Za naprosto alarmující lze označit stav, kdy obec nedosáhla kladného salda v provozním rozpočtu ani $\mathrm{v}$ tř́letém souhrnu za sledované roky 2009-2011. V Jihomoravském kraji se v této situaci ocitlo celkem 32 obcí. Tyto obce nejenže za sledované tři roky nedokázaly uspořit žádné prostředky, ale nedokázaly ani financovat svůj provoz z běžných prŕímů a musely hledat zdroje na jeho dofinancování - bud' formou rozpouštění úspor, prodeje majetku, nebo zvýšení svého zadlužení.

\section{Obr. 2: Procentní zastoupení obcí se zápornou výší salda provozního rozpočtu}

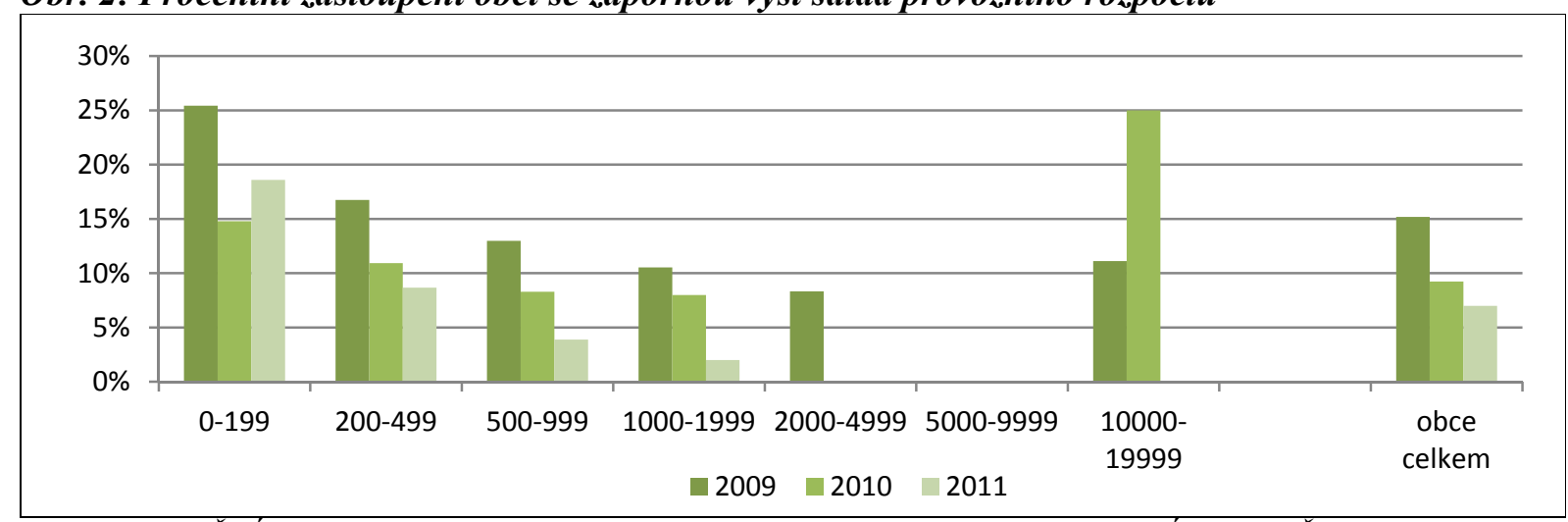

Zdroj: ČSÚ:počet obyvatel v obcích k 1.1.2009, 2010, 2011; databáze ARIS, ÚFIS MFČR; Závěrečný účet statutárniho města Brna za rok 2009, 2010, 2011. Vlastni zpracování.

Finanční kondici obce ovlivňuje nejen schopnost generovat zdroje z přebytku provozního rozpočtu, ale pochopitelně také současná úroveň zadlužení obce a s tím související nároky na financování v následujících letech. Následující graf prezentuje procentní zastoupení zadlužených obcí dle jednotlivých velikostních kategorií. Podíl zadlužených obcí je rostoucí s rostoucí velikostní kategorií (s mírným poklesem v kategorii 5000-9999 obyvatel). Celkově je zadluženo přes padesát procent obcí. 


\section{Obr. 3: Podíl zadlužených obcí JMK dle velikostních kategorií}

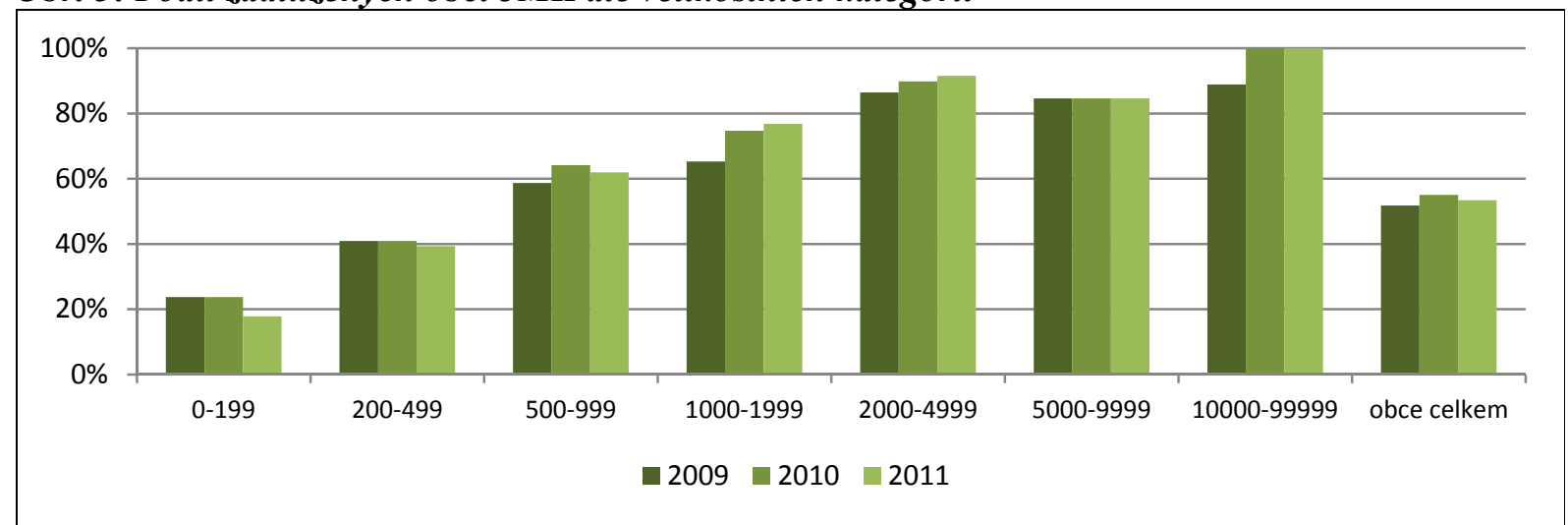

Zdroj: ČSÚ:počet obyvatel v obcich k 1.1.2009, 2010, 2011; databáze ARIS, ÚFIS MFČR; Závěrečný účet statutárního města Brna za rok 2009, 2010, 2011. Vlastní zpracování.

Průměrná výše zadluženi (v přepočtu na obyvatele) dle velikostnich kategorií nevykazuje velmi výrazné rozdíly, jejich grafické znázorněni (v následujicím grafu) odpovídá plošši křivce ve tvaru „,U“. Průměr za všechny obce výrazně zvyšuje zadluženost statutárního města Brna. 3 Na zadluženosti obcí JMK se nejvíce podílejí úvěry. V letech 2009 a 2010 se na druhém místě umístily komunální dluhopisy, ty však mělo emitované pouze Brno, v roce 2011 došlo k jejich splacení. Návratné finanční výpomoci mezi rozpočty se na celkové zadluženosti podílejí pouze minimálně.

Obr. 4: Průměrná výše zadluženosti na 1 obyvatele zadlužených obcí JMK dle velikostních

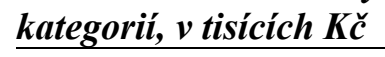

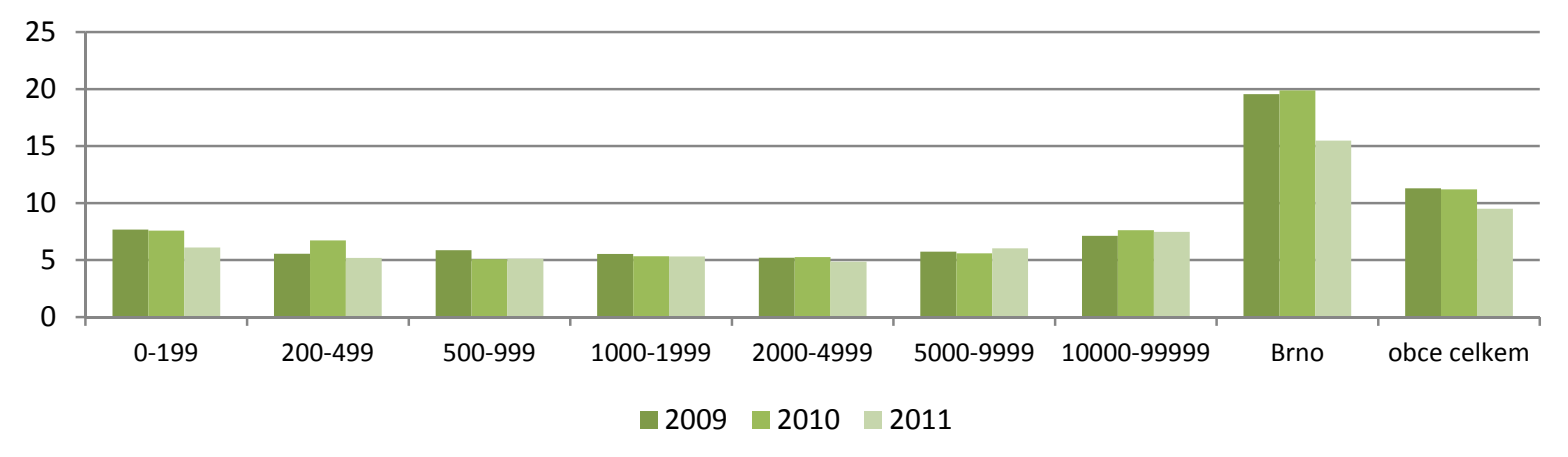

Zdroj: ČSÚ:počet obyvatel v obcích k 1.1.2009, 2010, 2011; databáze ARIS, ÚFIS MFČR; Závěrečný účet statutárního města Brna za rok 2009, 2010, 2011. Vlastni zpracování.

Ukazatel UZ1 vyjadřuje podíl dluhové služby a dluhové kapacity. Do dluhové služby vstupují roční výdaje související se splácením dluhů, tedy zejména placené úroky, splátky jistin a poměrná výše splátek emitovaných dluhopisư ${ }^{4}$. Dluhová kapacita je vyjádřena jako přebytek provozního rozpočtu, tedy rozdíl běžných př́immů a běžných výdajů; do běžných výdajů pro tyto účely nejsou zahrnuty výdaje na dluhovou službu. Ukazatele vyjadřují, zda a s jakou rezervou je obec schopna hradit své závazky související se zadlužením z přebytku svého běžného rozpočtu. Ukazatele je možné využít jak pro srovnání schopnosti obcí splácet své dluhy, tak také pro hodnocení vývoje hospodaření obce, také pro plánování budoucích aktivit obce. Následující graf představuje hodnoty mediánu ukazatele UZ1, vzhledem $\mathrm{k}$ vysoké variabilitě výsledků jednotlivých obcí hodnota aritmetického průměru nemá dostatečnou vypovídací schopnost.

\footnotetext{
${ }^{3}$ Pokles zadluženosti Brna v roce 2011 byl způsoben splacením emise komunálních dluhopisů.

${ }^{4} \mathrm{~V}$ př́ípadě zahrnutí celkové výše splátky $\mathrm{v}$ jednom roce splatnosti by došlo k neúměrnému navýšení dluhové služby. Je uplatněn předpoklad, že město, které emitovalo dluhopisy, po celou dobu do jejich splatnosti shromažd'uje průběžně prostředky na tuto splátku, proto tedy do dluhové služby vstupují pouze celkové splátky dělené počtem let splatnosti.
} 
Obr. 5: Hodnoty mediánu ukazatele dluhové služby na přebytku provozního rozpočtu dle velikostních kategorií obcí JMK

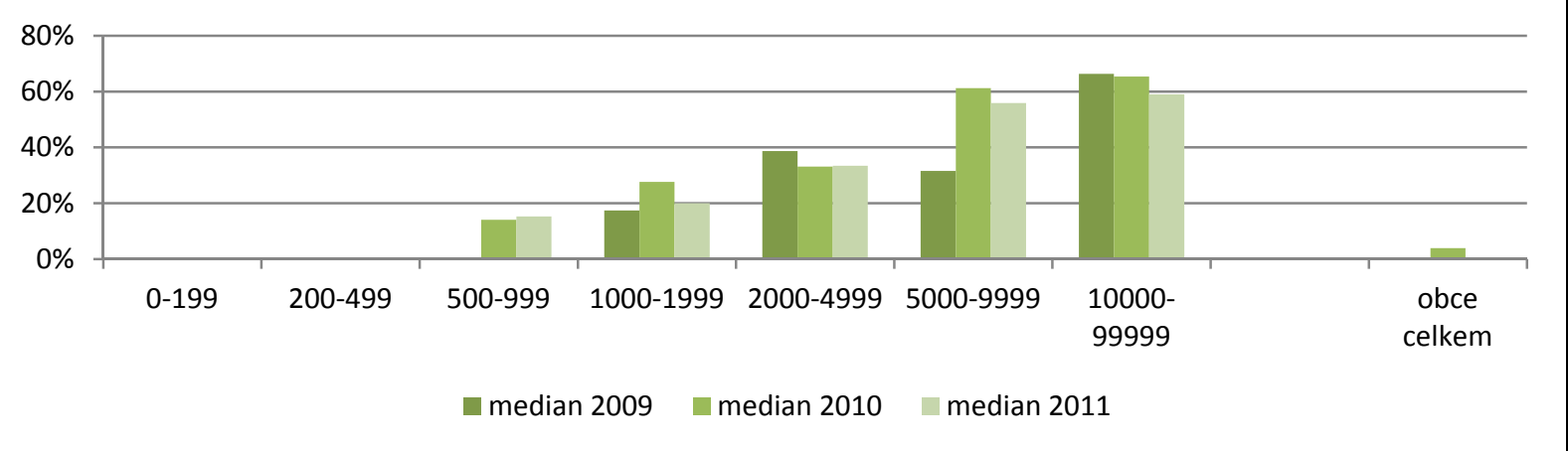

Zdroj: ČSÚ:počet obyvatel v obcich k 1.1.2009, 2010, 2011; databáze ARIS, ÚFIS MFČR; Závěrečný účet statutárniho města Brna za rok 2009, 2010, 2011. Vlastní zpracování.

Vzhledem k vysokému počtu obcí, které vykazují nulovou zadluženost (a tedy UZ1 je roven nule), je další výpočet proveden pouze pro zadlužené obce, které vykazují kladné hodnoty ukazatele UZ1. Hodnoty průměru a mediánu ukazatele těchto obcí prezentuje následující graf. Obce se zápornou hodnotou ukazatele (tedy se záporným provozním saldem) nebyly do výpočtu zahrnuty, protože by neadekvátně snižovaly výsledné hodnoty za velikostní kategorie.

\section{Obr. 6: Průměr a medián kladných hodnot UZ1}

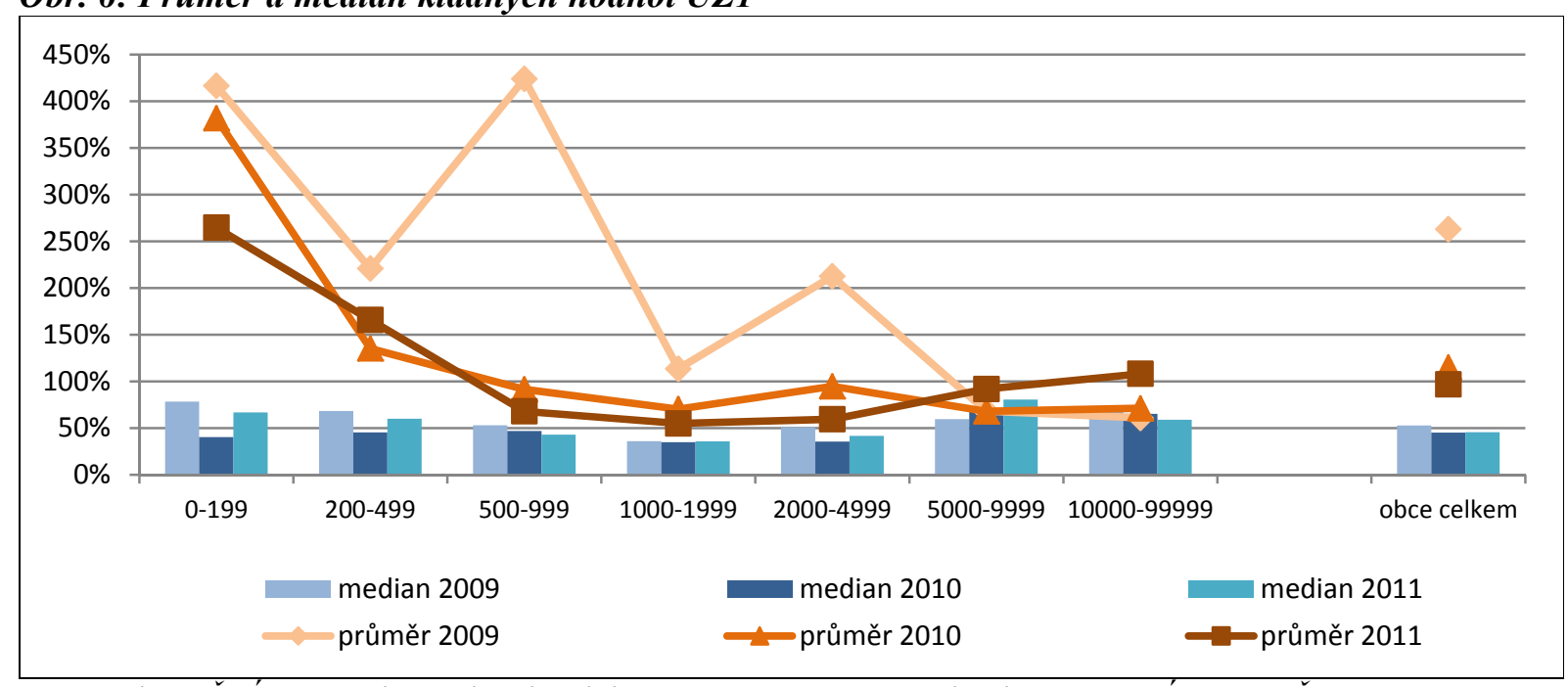

Zdroj: ČSÚ:počet obyvatel v obcich k 1.1.2009, 2010, 2011; databáze ARIS, ÚFIS MFČR; Závěrečný účet statutárniho města Brna za rok 2009, 2010, 2011. Vlastni zpracování.

Následující graf prezentuje zastoupení obcí, které vykazují potenciálně problémovou finanční situaci:

- Obce, jejichž ukazatel UZ1 je záporný, což znamená, že obec nejenže dosahuje deficitu $\mathrm{v}$ provozní části rozpočtu, ale navíc musí v daném roce vynakládat prostředky na dluhovou službu.

- Obce, které sice dosahují kladného salda provozního rozpočtu, nicméně tento přebytek je nižší než dluhová služba a obec musí nalézt prostředky na splátky v jiných zdrojích (UZ1 větší než 1). 
Obr. 7: Procentní zastoupení obcí se záporným výsledkem ukazatelem dluhové služby na přebytku provozního rozpočtu nebo s výsledkem větším než 1

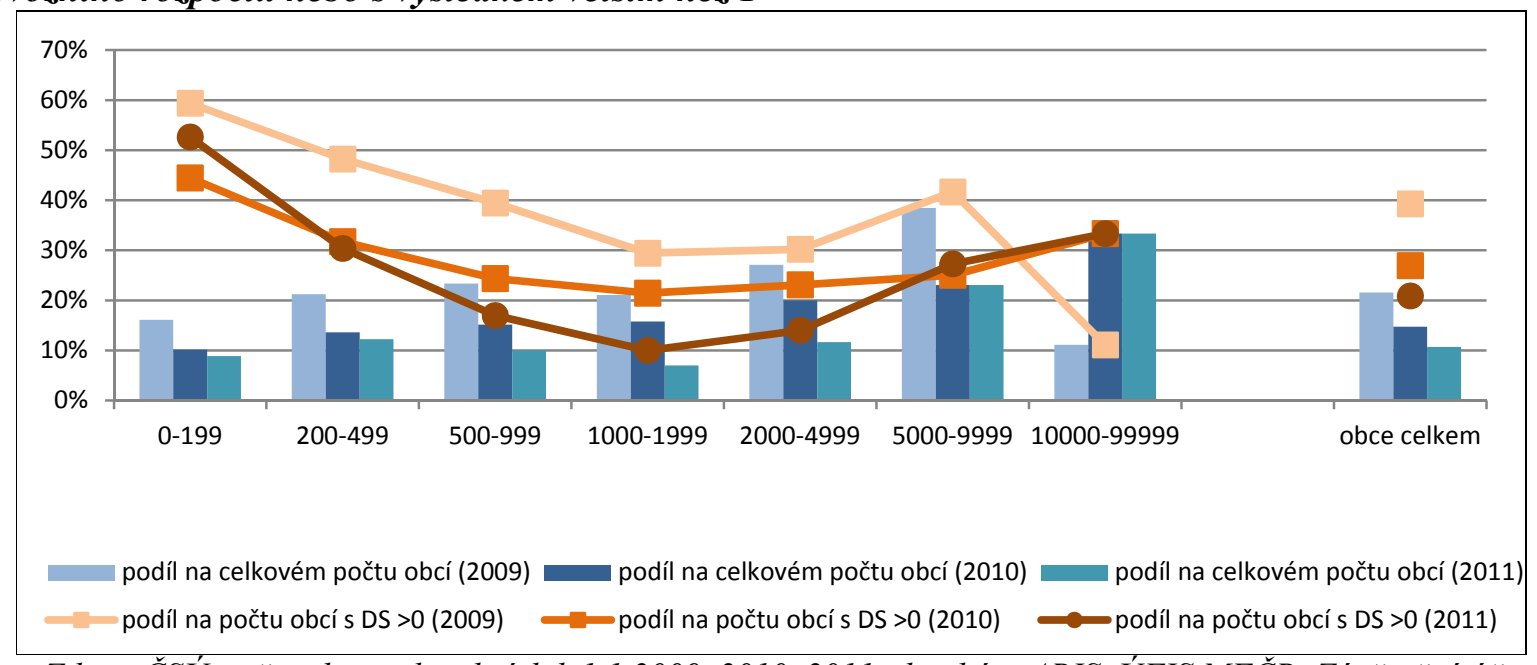

Zdroj: ČSÚ:počet obyvatel v obcích k 1.1.2009, 2010, 2011; databáze ARIS, ÚFIS MFČR; Závěrečný účet statutárniho mèsta Brna za rok 2009, 2010, 2011. Vlastní zpracování.

Ukazatel UZ2 vyjadřuje, za kolik let by byl celkový dluh splacen ze salda provozního rozpočtu obce. Výpočet vychází pouze $\mathrm{z}$ výše provozního salda za daný kalendářní rok, ve své základní podobě nebere $\mathrm{v}$ úvahu jeho možné změny $\mathrm{v}$ následujících letech. Pro účely této studie a $\mathrm{z}$ důvodu vyloučení možných jednorázových výkyvů $\mathrm{v}$ provozním rozpočtu byl ukazatel vypočítán $\mathrm{s}$ využitím průměrné výše provozního salda za roky 2009-2011. Ukazatel nebere v úvahu splátkové kalendáře jednotlivých dluhů obce (úvěrů, půjček,...), na druhou stranu umožňuje jednoduché vyjádření schopnosti obce hradit své dluhy z „provozního zisku“. Ukazatel je vhodný ke komparaci schopnosti obcí generovat zdroje potřebné ke splácení svých dluhů. Je rovněž vhodný pro plánování budoucích výdajů obce při znalosti zatížení budoucích rozpočtů současným dluhovým zatížením.

Následující obrázek prezentuje hodnoty aritmetického průměru a mediánu ukazatele UZ2 dle velikostních kategorií. Nelze vysledovat jednoznačný trend, avšak významnou odchylku vykazují obce ve velikostní kategorii 5000-9999 obyvatel. Jedná se o středně velká města, která mají plnit široké spektrum městoobslužných i městotvorných funkcí srovnatelné s většími městy, ale nedisponují dostatečnými zdroji (tato problematika je odbornou veřejností diskutována např. i v souvislosti s nastavením rozpočtového určení daní). Tato města navíc na rozdíl od obcí a menších měst musí též plnit rozsáhlejší úkoly v oblasti přenesené působnosti, které nejsou vždy plně pokryty př́íspěvky od státu.

Obr. 8: Průměrné výsledky ukazatele podílu celkového dluhu obce v roce 2011 a průměrného provozního salda za roky 2009-2011 - výsledky za zadlužené obce JMK celkem

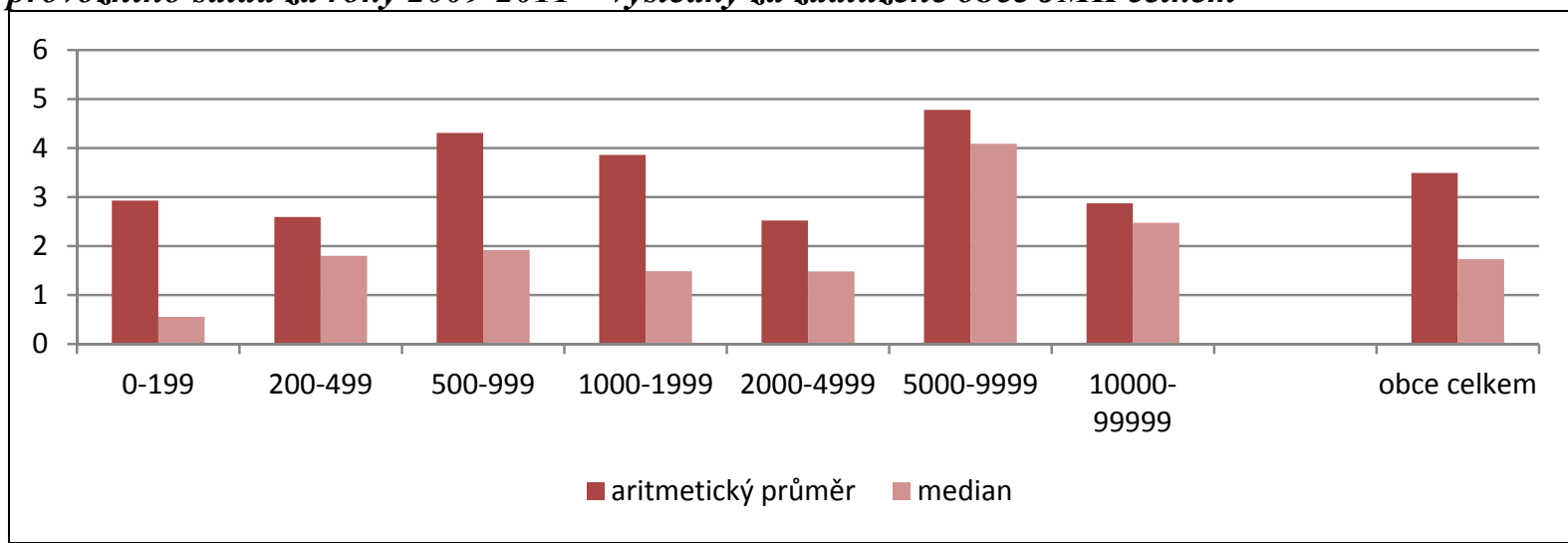

Pozn.: Aritmetický průměr a medián je vypočten z kladných hodnot výsledkü ukazatele UZ2.

Zdroj: ČSÚ:počet obyvatel v obcich k 1.1.2009, 2010, 2011; databáze ARIS, ÚFIS MFČR; Závěrečný účet statutárního města Brna za rok 2009, 2010, 2011. Vlastni zpracování. 
Na základě výsledků ukazatele UZ2 tak lze identifikovat 359 zadlužených obcí, které vykazují kladný průměrný přebytek provozního rozpočtu. Z nich 301 dosahuje výsledku do hodnoty 5 (tedy schopnost splatit své dluhy z provozního rozpočtu do pěti let), což představuje přibližně $81 \%$ zadlužených obcí. (do deseti let je schopno své dluhy splatit přibližně $92 \%$ zadlužených obcí). Dalších 11 obcí vykazuje zadlužení, avšak nedosahuje úspor v provozním rozpočtu. Tento stav je možné označit za velmi závažný.

\section{Omezení modelu}

Výsledky zvoleného způsobu hodnocení finanční kapacity obcí mohou být ovlivněny několika faktory:

- Volba ukazateli̊. Volba ukazatelů je do určité míry subjektivní záležitostí hodnotitele. Některé ukazatele mohou mít výrazně pozitivní vliv na hodnocení obcí určité velikostní kategorie obcí.

- Interpretace výsledki̊ ukazatelio. Vypovídací schopnost ukazatelů je ovlivněna různými faktory. Bez jejich znalosti nelze jednoznačně určit, zda špatné výsledky ukazatele skutečně znamenají špatné finanční zdraví v dané oblasti. Špatný výsledek je tedy pouze SIGNÁLEM naznačujícím velmi pravděpodobné, avšak ne stoprocentně jisté problémy ve finanční kondici obce.

- Časový horizont. Studie sleduje finanční situaci obcí za období 3 let. Nicméně některé procesy a aktivity obce mají dlouhodobější charakter, který není možné zvolenou metodikou plně postihnout.

- Platná legislativa upravující rozpočtování, účtování a výkaznictví. Tato legislativa ovlivňuje typy dat a způsoby jejich vykazování v účetních výkazech obcí.

- Veřejná data, z nichž jsou vypočítány výsledky. Práce čerpá z veřejně dostupných finančních výkazů obce. Model čerpá pouze z veřejně dostupných finančních výkazů obce, tedy nemůže pro výpočty ukazatelů využít detailnější interní data subjektů.

- Lidský faktor na straně obcí. Data jsou získána z výkazů od 672 subjektů, existuje tedy určité riziko špatných údajů ve výkazech $\mathrm{z}$ důvodu lidského faktoru $\mathrm{v}$ daných obcích (zejména v malých obcích obce nedisponují rozsáhlým odborným personálním zabezpečením, i v souvislosti napřs. s probíhající účetní reformou, lze očekávat chyby ve výkazech).

\section{Závĕr}

Obce dosahují přebytku provozního rozpočtu v průměru ve výši $20 \%$ svých běžných př́ijmů. V roce 2009 byl tento průměr nižší, což bylo způsobeno dopadem finanční krize na veřejné rozpočty, propadem výše daňových příjmů obcí. Menší obce dosahují vyšších úspor v procentním vyjádření než středně velká a velká města ( $\mathrm{v}$ absolutních částkách je situace pochopitelně jiná). Na druhou stranu však právě v kategoriích nejmenších obcí je větší zastoupení obcí, které v provozní části rozpočtu dosahují záporného salda. Tato situace může být jednoročně způsobena výkyvem bud' na straně běžných výdajů (neočekávané výdaje související např. s prŕírodní pohromou), nebo na straně př́ijmů (např̀. neočekávaně vysoký propad daňových př́ijmů v důsledku finanční krize); v případě opakujícího se záporného salda provozního rozpočtu však jde o alarmující stav, kdy obec není dlouhodobě schopna pokrýt své provozní výdaje z běžných, každoročně se opakujících př́íjmů.

Z hlediska finanční kapacity obce je podstatnou informací absolutní výše přebytku provozního salda rozpočtu, který může obec použít bud' přímo na financování investic (kapitálových výdajů), anebo na splácení dluhů, které obec přijala na financování investic. V př́ípadě hodnocení možnosti obce přijímat nové dluhy a schopnosti je splácet je třeba vzít v úvahu stávající zadlužení a jeho zátěž na rozpočet obce. Jinými slovy, pokud se obec rozhodne financovat své investice formou dluhů, měla by být schopná pokrýt roční náklady na zadlužení (tj. splátky úmoru a úroků) z přebytku svého provozního rozpočtu sníženého o stávající splátky dluhů (pokud není k financování těchto potřeb vyčleněn majetek k prodeji). Záleží též na charakteru pořizované investice (jaký vliv bude mít její uvedení do provozu na provozní rozpočet). 


\section{Obr. 9: Obce s problematickou finanční kapacitou*}

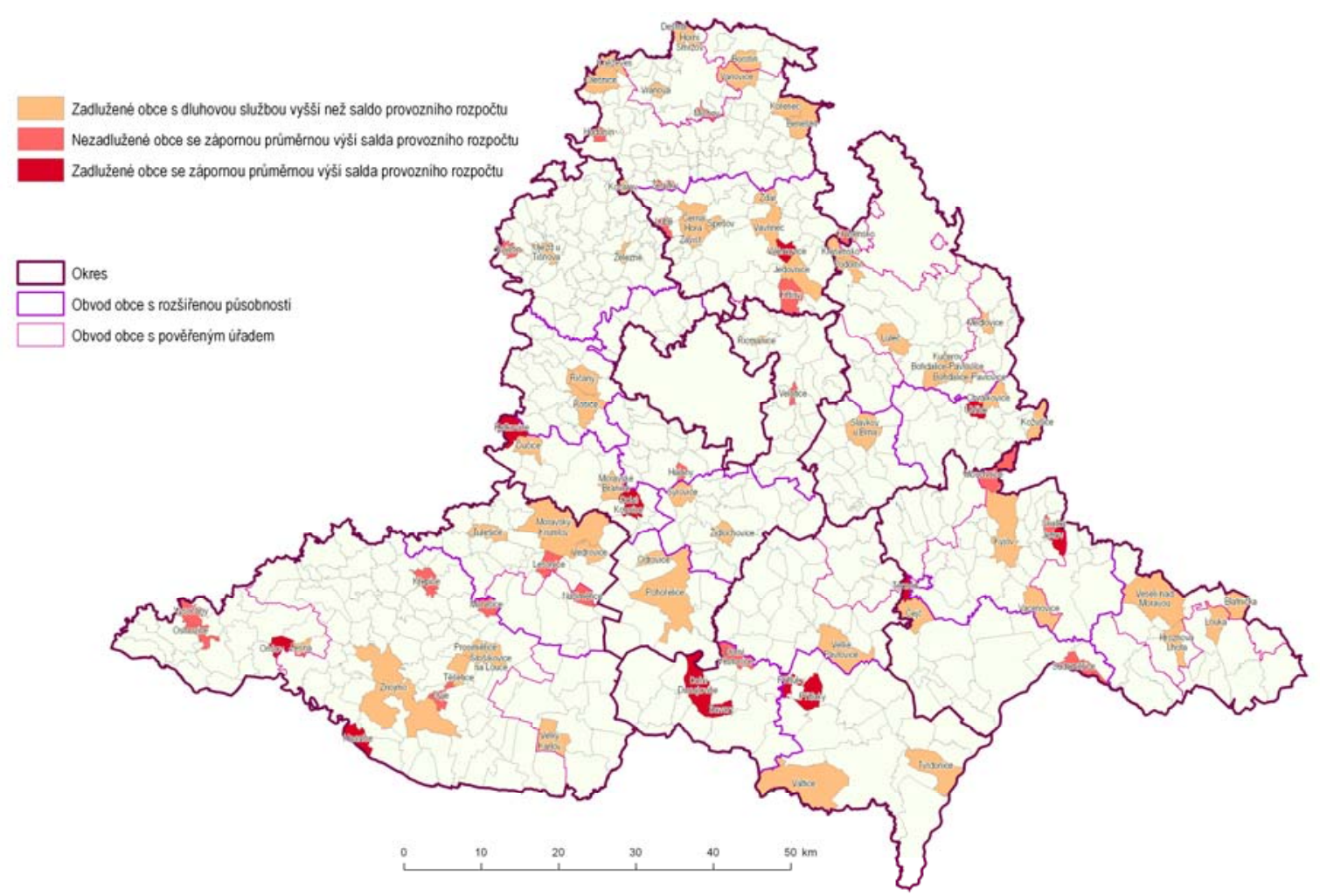

Zdroj: ČSÚ:počet obyvatel v obcích k 1.1.2009, 2010, 2011; databáze ÚFIS MFČR; Závěrečný účet statutárního města Brna za rok 2009, 2010, 2011. Kartogram zpracoval Mgr. Petr Tonev. * Zadlužené obce s dluhovou službou vyšší než saldo provozního rozpočtu - výpočet za rok 2011; Nezadlužené obce se zápornou průměrnou výší salda provozního rozpočtu - průměr za r. 2009-2011; Zadlužené obce se zápornou výší salda provozního rozpočtu - průměr za r. 2009-2011

Finanční kapacita obcí je ovlivněna nejen možnostmi obce vytvářet úspory (zejména v provozní části rozpočtu), ale také současnou úrovní zadlužení a z ní vyplývajícími požadavky na finanční prostředky z rozpočtu. $V$ Jihomoravském kraji je zadluženo přibližně $50 \%$ všech obcí, přitom podíl zadlužených obcí roste s rostoucí velikostní kategorií (tento trend odpovídá i celorepublikovému trendu).

O nárocích dluhové služby na rozpočet vypovídá ukazatel UZ1, který udává, jaký podíl z (případného) přebytku provozního rozpočtu obce musí obec použít na splácení svých dluhů. Jako špatnou lze označit situaci v obcích, kde výdaje na dluhovou službu opakovaně překračují výši provozního rozpočtu. Kritická situace pak nastává v obcích, které musejí splácet své úvěry a půjčky, avšak zároveň v provozním rozpočtu (dlouhodobě) hospodaří deficitně.

Ukazatel UZ2 vypočítává, za kolik let by teoreticky byly obce schopné splatit své dluhy pouze při použití prostředků $\mathrm{z}$ přebytku provozního rozpočtu (za předpokladu, že průměrný přebytek za uplynulé tři roky lze očekávat i do budoucna). Více než $80 \%$ zadlužených obcí by bylo schopno splatit své dluhy do 5 let. V př́ípadě 6 obcí však hrozí, že obce nebudou schopné tímto způsobem splatit své dluhy do méně jak 20 let. $\mathrm{V}$ př́ípadě, že má obec přijatý úvěr, na jehož splacení bude $\mathrm{v}$ dalších letech čerpána dotace, nelze tuto skutečnost $\mathrm{z}$ veřejně dostupných dat zjistit a tedy ani postihnout ve výpočtu ukazatele.

Finanční kapacitu obce ovlivňuje její současná výše úspor (a také majetek obce, jehož prodejem by obec mohla získat potřebné zdroje). Klíčovou pro možnost dosahování úspor je schopnost obce dosahovat kladného salda $\mathrm{v}$ provozní části rozpočtu. V př́ípadě, že obec musí splácet závazky ze zadlužení, jsou tyto nároky na přebytkové hospodaření v provozním rozpočtu o to vyšší. Následující 
kartogram prezentuje obce s rizikovou situací ve své finanční kapacitě. Tyto obce lze rozdělit do tř́ kategorií dle závažnosti rizika od menšího k nejvyššímu (Jejich geografické rozložení viz následující obrázek):

- Zadlužené obce s dluhovou službou vyšší než saldo provozního rozpočtu - tyto obce sice vykazují přebytky v provozní části rozpočtu, avšak tento přebytek není dostačující pro splácení ročních nákladů na zadlužení a obec tak musí tyto prostředky hledat jinde (v př́padných úsporách z minulých let - má-li je k dispozici, v prodeji majetku, v dalším zadlužování).

- Nezadlužené obce se zápornou výší salda provozního rozpočtu - obce, které nejsou schopné pokrýt své provozní výdaje ze svých běžných př́ijmů. Vzhledem k možnému jednoročnímu výkyvu (z důvodů např. zvýšených výdajů na odstranění následků živelných pohrom) je vhodné zabývat se touto problematikou z dlouhodobějšího pohledu.

- Zadlužené obce se zápornou výší salda provozního rozpočtu - obce s nejhorší situací, které nejenže nejsou schopné pokrýt své běžné (provozní) výdaje z běžných př́ijmů, navíc musejí také hradit výdaje na dluhovou službu.

V případě těchto obcí je klíčové detailněji analyzovat př́ijmovou a zejména výdajovou stránku provozní části rozpočtu a nalézt způsoby, jak bud’ navýšit své běžné př́ijmy, nebo (a to spíše) které provozní výdaje lze snížit, ušetřit. Jedině dlouhodobě přebytkové hospodaření v provozní části rozpočtu umožní obci generovat dostatek zdrojů pro svůj rozvoj.

\section{Literatura}

[1] Aktuální znění zákonů a vyhlášek České republiky - databáze ASPI

[2] ČESKÝ STATISTICKÝ ÚŘAD. Počet obyvatel v obcich k 1.1.2009, ČSÚ. Dostupné z: $<\mathrm{http} / /$ www.czso.cz/csu/2009edicniplan.nsf/publ/1301-09-k_1_1_2009>.

[3] ČESKÝ STATISTICKÝ ÚŘAD. Počet obyvatel v obcich $k$ 1.1.2010, ČSÚ. Dostupné z: $<$ http://www.czso.cz/csu/2010edicniplan.nsf/pub1/1301-10->.

[4] ČESKÝ STATISTICKÝ ÚŘAD. Počet obyvatel v obcich k 1.1.2011, ČSÚ. Dostupné z: $<\mathrm{http} / / / w w w . c z s o . c z / c s u / 2011$ edicniplan.nsf/publ/1301-11-r_2011 >.

[5] ČESKÝ STATISTICKÝ ÚŘAD. Územně identifikační registr základních územních jednotek, ČSÚ, 2011 [cit. 12.3. 2012]. Dostupné z: <http://www.czso.cz/csu/rso.nsf/i/prohlizec_uir_zsj>.

[6] Databáze ARIS MFČR. Dostupné z: <http://wwwinfo.mfcr.cz/aris/>.

[7] Databáze ÚFIS MFČR. Dostupné z: <http://wwwinfo.mfcr.cz/ufis/>.

[8] eCBA s.r.o. Finanční kapacita obcí Jihomoravského kraje -výzkum 2009-2011. Brno, 2013.

[9] MINISTERSTVO FINANCÍ ČESKÉ REPUBLIKY. Monitoring hospodařeni obcí. Dostupné z: $<\mathrm{http} / / \mathrm{www} . \mathrm{mfcr} . \mathrm{cz} / \mathrm{cps} / \mathrm{rde} / \mathrm{xchg} / \mathrm{mfcr} / \mathrm{xsl} / \mathrm{vf}$ monitoring hospodareni obci.html $>$.

[10] OPLUŠTILOVÁ, I. Finanční zdraví obci a jeho regionální diferenciace. [Disertační práce] Brno> Masarykova univerzita, 2012.

[11]STATUTÁRNÍ MĚSTO BRNO. Závěrečný účet statutárního města Brna za rok 2009 Vyúčtování hospodařeni a finančni vypořádání. 2010. Dostupné $\mathrm{z}:<\mathrm{http} / / / \mathrm{www} . b r n o . c z /$ spravamesta/dokumenty-mesta/rozpocet/plneni-rozpoctu-statutarniho-mesta-brna/zaverecny-ucetstatutarniho-mesta-brna-za-rok-2009-vyuctovani-hospodareni-a-financni-vyporadani/>.

[12] STATUTÁRNÍ MĚSTO BRNO. Závěrečný účet statutárního města Brna za rok 2010 Vyúčtováni hospodařeni a finančni vypořádání. 2011. Dostupné $\mathrm{z}:<\mathrm{http} / / / \mathrm{www} \cdot b r n o . c z / s p r a v a-$ mesta/dokumenty-mesta/rozpocet/plneni-rozpoctu-statutarniho-mesta-brna/zaverecny-ucetstatutarniho-mesta-brna-za-rok-2010-vyuctovani-hospodareni-a-financni-vyporadani/>.

[13] STATUTÁRNÍ MĚSTO BRNO. Závěrečný účet statutárního města Brna za rok 2011 Vyúčtováni hospodařeni a finančni vypořádání. 2012. Dostupné z: <http://www.brno.cz/spravamesta/dokumenty-mesta/rozpocet/plneni-rozpoctu-statutarniho-mesta-brna/zaverecny-ucetstatutarniho-mesta-brna-za-rok-2011-vyuctovani-hospodareni-a-financni-vyporadani/>. 